\title{
THE COMPATIBILITY STUDENT CHOICE OF UNIVERSITY MAJORING; A PRELIMINARY STUDIES
}

\author{
Daharnis \\ Universitas Negeri Padang \\ daharnis@konselor.org \\ Zadrian Ardi \\ Universitas Negeri Padang \\ zadrian@fip.unp.ac.id
}

\begin{abstract}
The continuous improvements in order to optimize the basic education to higher education are still running. Based on that purpose, there are many factors to supporting the students' learning activities success; one of the factors is suitability with majors in university. The purpose of this study is to reveal the condition of the compatibility of student majoring with their interest, then to describe the information when the student choose their majoring. Sample in this study was 122 peoples, taken by random sampling from the Padang State University. Data obtained by distributing questionnaires. The results showed that there are students that their major do not match with their interest (22.13\%), only $3.28 \%$ of students who feel compatible with their major. This result should be a major concern, particularly for counselor in school for design counseling services to solve these problems. The result of this study used as a grand tour or a preliminary study for further research.
\end{abstract}

Keywords: choice of university majoring, matches, counseling, career

\section{PENDAHULUAN}

Salah satu peningkatan yang cukup signifikan dalam taraf kehidupan masyarakat Indonesia adalah dalam sektor pendidikan terutama pendidikan tinggi. Hal ini dibuktikan dengan telah tersedianya 3.280 perguruan tinggi negeri dan swasta dan sebanyak 5,8 juta mahasiswa atau $2,31 \%$ dari total populasi penduduk Indonesia (Badan Pusat Statistik Indonesia, 2016). Peningkatan tersebut juga diiringi dengan perumusan berbagai kebijakan-kebijakan pemerintah yang berkenaan dengan tujuan pendidikan secara umum. Perubahan tersebut dilakukan dalam tatanan teknis (berkenaan dengan pengaturan kalender, seleksi, aturan dan disiplin) serta hal-hal dasar terkait kurikulum secara komprehensif. Perbaikan-perbaikan tersebut dilakukan dalam rangka mencapai generasi emas pada tahun 2045 dan memenuhi tujuan pendidikan di Indonesia, sebagaimana tercantum dalam Peraturan Pemerintah Nomor 32 Tahun 2013 tentang Standar Nasional Pendidikan.

Berbagai aturan dan kebijakan tersebut secara nyata mengatur mekanisme pendidikan lanjutan untuk setiap jenjang pendidikan. Pendidikan dasar yang terdiri dari SD/MI memiliki arah pendidikan lanjutan berupa pendidikan menengah yakni SMP/MTs, yang pada muaranya akan dilanjutkan dengan pendidikan menengah yang lebih tinggi berupa SMA/SMK/MA/MAK sesuai Permendikbud Nomor 68 tahun 2013 tentang Kerangka Dasar dan Struktur Kurikulum Sekolah Menengah Pertama/Madrasah Tsanawiyah dan Permendikbud nomor 58 tahun 2014 tentang Kurikulum 2013 Sekolah Menengah Pertama/Madrasah Tsanawiyah 
(Kementerian Pendidikan dan Kebudayaan, 2014b; Kementerian Pendidikan Nasional, 2013). Dan untuk jenjang pendidikan SMA/SMK/MA/MAK jenjang pendidikan lanjutannya adalah pendidikan tinggi sebagaimana tertuang dalam Undang-undang nomor 12 tahun 2012 tentang pendidikan tinggi, Kerangka Kualifikasi Nasional Indonesia (KKNI), Standar Nasional Perguruan Tinggi serta berbagai arah dan kebijakan penyelenggaraan PT.

Keberhasilan siswa dalam proses pembelajaran di perguruan tinggi merupakan salah satu bentuk suksesnya penataan sistem pendidikan tinggi yang juga ditunjang oleh berbagai faktor pendukungnya. Kondisi aktivitas belajar merupakan salah satu faktor kuat yang menunjang kesuksesan belajar mahasiswa (Kim \& Hwang, 2014; Kutty, 2014; Nyamwange, 2016; Sojkin, Bartkowiak, \& Skuza, 2015). Lebih jauh, aktivitas belajar mahasiswa dimaksud akan sangat dipengaruhi oleh berminat atau tidaknya mahasiswa dengan jurusan yang saat ini mereka tempati (Albert \& Garcı' a-Serrano, 2010; Daharnis dkk, 2011; Elliot, Kratochwill, Littlefield, \& Travers, 1996; Erlamsyah dkk, 2011; Klein \& Washburn, 2012; Kutty, 2014; Mupemhi, 2013; Pablolerchundi, Núñez-del-Río, \& GonzálezTirados, 2015; Tereza, 2013; Timothy, 2010).

Mahasiswa yang merasa minatnya cocok dengan jurusan yang ditempatinya saat ini akan memiliki aktivitas belajar yang cukup baik (Khan, Ahamad, \& Kousar, 2015; Lang \& Lopes, 2014; Mupemhi, 2013), begitupun sebaliknya. Kondisi ketidakcocokan pada hakikatnya mesti menjadi perhatian serius terutama oleh guru BK di lapangan. Terjadinya kondisi ketidakcocokan dapat disebabkan oleh berbagai faktor antara lain pihakpihak terkait tidak menjalankan fungsi sebagaimana mestinya dalam rangka membantu siswa mengeksplorasi karir sesuai dengan tahap perkembangan karir siswa SLTA yang berada pada tahap eksprolari karir (S. D. Brown \& Lent, 2013), dimana tahap penting ini akan dilalui siswa yang sedang berada pada jenjang SLTA serta membutuhkan banyak informasi terkait (Gladding, 2009).

Seperti telah dikemukakan sebelumnya, salah satu pihak yang memiliki peran penting dalam mengenalkan minat dan kecocokan dengan jurusan tersebut adalah guru BK/Konselor di sekolah, sehingga bersama guru BK/Konselor tersebut siswa dapat merencanakan pendidikan lanjutan sebaik mungkin (Ardi, 2014; Herr \& Cramer, 1984; Kementerian Pendidikan dan Kebudayaan, 2013, 2014a; Prayitno, 2009). Namun, permasalahan yang muncul adalah bagaimana kondisi kecocokan mahasiswa dengan jurusan yang saat ini mereka tempati? Apakah ketersediaan guru BK/Konselor di sekolah telah memiliki pengaruh tertentu terhadap informasi jurusan yang mahasiswa peroleh saat ini? Dalam menjawab pertanyaan-pertanyaan tersebut, penulis melakukan studi pendahuluan untuk mengetahui sejauh mana kecocokan mahasiswa dengan jurusan yang mereka tempati dengan minatnya serta kondisi informasi dan keberadaan guru BK/Konselor di lapangan. Hal ini dilakukan dengan tujuan untuk mendapatkan data awal (grand tour) dalam mengembangkan penelitian lebih lanjut

\section{Memilih Program Studi}

Siswa yang akan melanjutkan pendidikan ke perguruan tinggi berada pada fase remaja sebagai periode transisi, dimana akan mengalami banyak perubahan dan penyesuaian. Kondisi yang kompleks tersebut menuntut penguasaan berbagai kompetensi dan kemampuan diantaranya menghadapi masalah, 
bertindak sesuai aturan dan norma dan bertanggung jawab (Ahmadi, 1991; Ardi, Ibrahim, \& Said, 2012). Kondisi penyesuain tersebut menuntut adanya perubahan-perubahan, salah satu perubahan yang cukup signifikan adalah mengembangkan suatu perencanaan, rasa tanggung jawab, orientasi masa depan, eksperimen dan eksplorasi diri, memeriksa identitas diri serta merencanakan jalur karir serta gaya hidup yang akan dijalani di masa depan (Keller, Samuel, Bergman, \& Semmer, 2014; Santrock \& Halonen, 2010).

Periode transisi tersebut merupakan skema yang kompleks dalam perkembangan karir siswa di masa depan. Proses tersebut akan melibatkan pemeriksaan diri, penyelaman informasi tentang studi di pendidikan tinggi serta pilihan karir yang tersedia setelah menamatkan pendidikan tinggi tersebut (Greenhaus \& Callanan, 2006).

Fase ini juga dinamakan dengan masa eksplorasi, dimana siswa melakukan upaya untuk memperoleh informasi tentang studi pendidikan lanjutan dan pekerjaan/prospek karir di masa depan untuk membuat sebuah piliah program studi. Secara rinci, fase ini bergerak dari pengembangan aspirasi karir hingga aktualisasi karir (kristalisasi, spesifikasi, dan aktualisasi) (D. Brown, 2002).

Selain itu, dalam memilih pendidikan lanjutan tersebut, terdapat berbagai hal yang harus diperhatikan siswa dan menjadi informasi penting yang mesti disampaikan oleh guru BK/Konselor. Pertama adalah dalam kondisi kehidupan sosial di perguruan tinggi tempat tujuan yang dipilih oleh siswa dimaksud, karena latar belakang etnis, geografis dan interaksi teman sebaya lebih beragam akan ditemui oleh siswa dimaksud (Santrock, 2014). Kedua, kondisi perkuliahan yang akan dihadapi oleh calon mahasiswa/siswa dimaksud akan berbeda jauh dibandingkan kondisi di sekolah (Santrock \& Halonen, 2010), antara lain:

1. Kelas kuliah yang jauh lebih besar, lebih kompleks, dan lebih impersonal. Guru di sekolah mungkin tahu nama sisswa dan mungkin bahkan seperti keluarga sendiri. Namun di perguruan tinggi, dosen mungkin tidak tahu nama mahasiswa atau mengenali wajah mahasiswa tersebut di luar kelas.

2. Di perguruan tinggi, kehadiran dan atensi di dalam kelas merupakan tanggung jawab masing-masing mahasiswa, jika ingin mendapatkan nilai yang baik maka mahasiswa harus bertanggung jawab terhadap dirinya sendiri.

3. Dalam perkuliahan, tes penguasaan materi akan diberikan lebih sedikit dibandingkan di sekolah, bahkan beberapa diantaranya tidak memberikan tes sama sekali.

4. Di perguruan tinggi, sangat jarang mahasiswa diperlakukan sebagai seorang anak, karena mahasiswa sudah dianggap sebagai seorang dewasa yang memiliki kemerdekaan, pilihan, dan tanggung jawab.

5. Mahasiswa harus lebih banyak lagi membaca, bahkan mahasiswa mungkin diharapkan untuk membuat keputusan sendiri tentang informasi apa yang didapatkan dari membaca.

6. Akan lebih banyak keragaman di perguruan tinggi, terutama dalam hal usia dan budaya sesama mahasiswa dan tenaga pengajar.

\section{Faktor Keberhasilan Pembelajaran Di Perguruan Tinggi}

Keberhasilan belajar mahasiswa di perguruan tinggi ditentukan oleh beragam faktor yang saling berkaitan satu sama lain. Secara umum, faktor-faktor tersebut dapat dikelompokkan menjadi faktor internal (berasal dari diri mahasiswa) dan faktor 
eksternal (berasal dari luar diri mahasiswa) (Daharnis, Erlamsyah, Alizamar, \& Afdal, 2011; Daharnis, 2005). Diantara faktor internal tersebut dirinci sebagai berikut:

1. Kondisi psikologis, antara lain: (a) kemampuan dasar umum/inteligensi, (b) bakat, (c) minat, (d) motivasi, (e) penguasaan

keterampilan/pengetahuan dasar, (f) kegiatan/kebiasaan dan gaya belajar, (g) aspirasi dan cita-cita, (h) kematangan dan kesiapan, (i) ketekunan, (j) konsentrasi, (k) locus of control, (l) perhatian, (m) ingatan, (n) persepsi.

2. Kondisi fisiologis, antara lain: (a) kondisi tubuh pada umumnya dan kesehatan, (b) kondisi panca indra, (c) cacat tubuh/fisik,

Sedangkan faktor eksternal dapat ditinjau dari segi :

1. Kondisi dalam keluarga, antara lain:

(a) hubungan antar sesama anggota keluarga, (b) kondisi sosial ekonomi keluarga (orang tua), (c) aspirasi dan persepsi angota keluarga tarutama terhadap pendidikan, (d) perhatian, (e) motivasi serta perlakuan orang tua/anggota keluarga terhadap kegiatan belajar siswa/mahasiswa

2. Kondisi kampus, antara lain: (a) kondisi fisik kampus, (b) kurikulum, (c) sarana dan prasarana, (d) karakteristik dosen dan personil lainnya, (e) suasana serta hubungan mahasiswa dengan dosen dan antar mahasiswa, (f) disiplin, (g) metode, (h) teknik, (i) media, (j) tugas-tugas yang harus dikerjakan mahasiswa, (k) pengelolaan pembelajaran, (l) penilaian, (m) umpan balik dan reward

3. Kondisi masyarakat, antara lain: (a) pergaulan dengan teman sebaya, (b) media masa, (c) dunia kerja, (d) nilai/norma masyarakat

Selain itu, ahli lain mengemukakan pengelompokan aspek-aspek yang berpengaruh terhadap proses pembelajaran dan karir mahasiswa di perguruan tinggi adalah dukungan keluarga, faktor psikologis, sistem pembelajaran dan minat terhadap jurusan yang ditempati (Khan et al., 2015). Gambaran faktor-faktor tersebut dapat dilihat pada Gambar berikut:

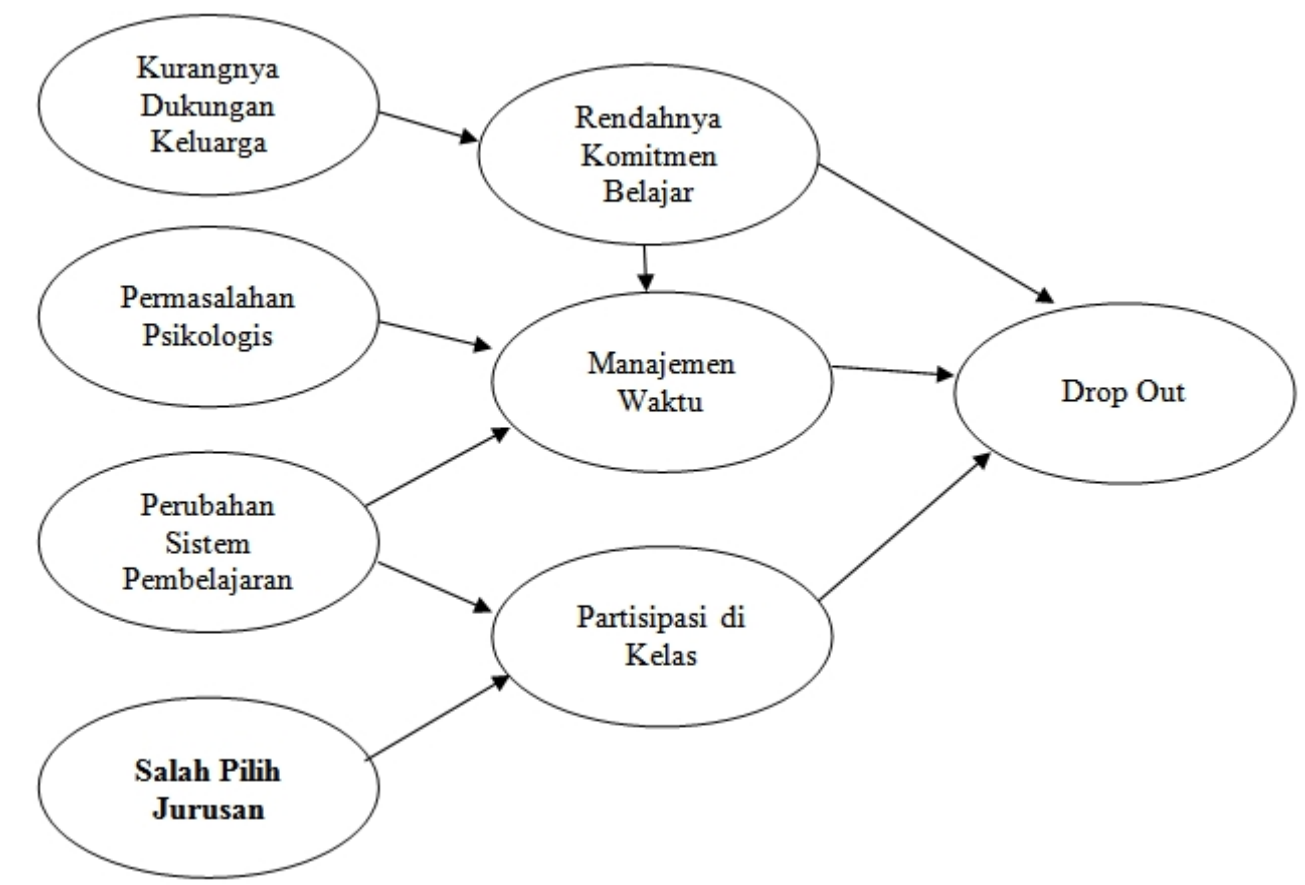

Gambar 1. Kondisi-kondisi yang menjadi faktor penyebab mahasiswa yang tidak berhasil (drop-out) (Khan et al., 2015) 
Dari gambar di atas dapat dimaknai bahwa salah satu hal yang menjadi kunci dalam pembelajaran mahasiswa adalah minat dengan jurusan yang ditempati. Hal ini akan berdampak langsung terhadap partisipasi di kelas dan pada akhirnya akan memiliki pengaruh cukup signifikan terhadap keberhasilan dan ketidakberhasilan (drop-out) mahasiswa dimaksud.

Berkenaan dengan siswa/calon mahasiswa, maka perlu adanya persiapan yang matang dalam menghadapi pendidikan lanjutan melalui peran bimbingan dan konseling dengan pengoptimalan segenap jenis layanan dan kegiatan pendukungnya (Prayitno, 2012). Kondisi lain yang diharapkan adalah adanya kesadaran siswa dalam mengembangkan wawasan dan informasi pendidikan lanjutan melalui pelayanan guru BK/Konselor, sehingga kepastian informasi mengenai pendidikan lanjutan, informasi bentuk perkuliahan, suasana akademik dan lain sebagainya dapat menjadi pertimbangan bagi siswa dalam perencanaan pendidikannya (Ardi \& Yendi, 2013; Santrock \& Halonen, 2010).

\section{METODE}

Subjek dalam penelitian ini adalah mahasiswa yang berada pada tahun satu perkuliahan yang terdiri dari 122 orang mahasiswa yang berasal dari berbagai jurusan di Universitas Negeri Padang. Sampel diambil secara acak untuk memenuhi kriteria kenormalan data. Jenis penelitian adalah penelitian deskriptif dengan proses pengambilan data melalui penyebaran sejumlah pertanyaan melalui kuisioner yang disusun sendiri oleh penulis berkaitan dengan materi yang akan diungkap (Babbie, 2010; Heppner, Wampold, \& Kivlighan, 2008; Lan, 2016; Mupemhi, 2013). Data dan keterangan yang diungkap melalui instrumen dimaksud berkenaan dengan kondisi kecocokan mahasiswa terhadap jurusan yang ditempati, kondisi keberadaan guru $\mathrm{BK} /$ Konselor, keinginan untuk pindah jurusan dan keinginan untuk mengulangi seleksi. Hasil studi tersebut merupakan grand tour yang selanjutnya akan dijadikan dasar pada penelitian lebih lanjut.

\section{HASIL DAN PEMBAHASAN}

Kondisi pertama yang diungkap melalui penelitian ini adalah gambaran kecocokan mahasiswa terhadap jurusan yang ditempati saat ini. Gambaran dimaksud diilustrasikan pada Grafik 1. Berdasarkan Grafik 1 dapat dimaknai bahwa sebanyak 22,13\% mahasiswa merasa tidak cocok dengan jurusan yang ditempatinya saat ini, dan hanya sekitar $3,28 \%$ mahasiswa yang merasa sangat cocok dengan jurusannya. Meskipun demikian, secara umum mahasiswa yang merasa cocok dengan jurusan yang ia tempati sebanyak 64,75\%. Kondisi ketidakcocokan tersebut pada hakikatnya akan membawa pengaruh terhadap kondisi aktivitas belajar mahasiswa.

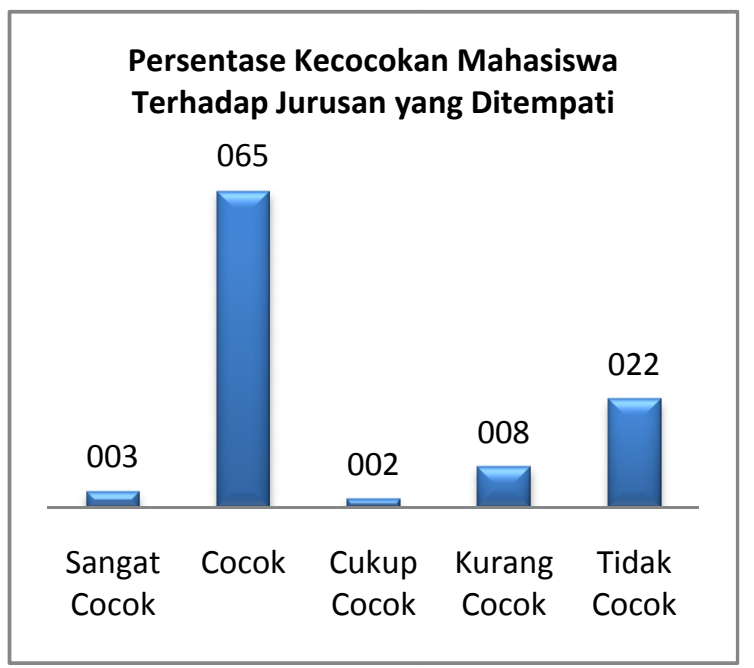

Grafik 1. Persentase Kecocokan

Hal ini cukup bertolak belakang dengan kenyataan bahwa 89,34\% mahasiswa justru telah mengetahui beberapa informasi mengenai jurusan yang 
ditempatinya, sebagaimana yang digambarkan pada Grafik 2.

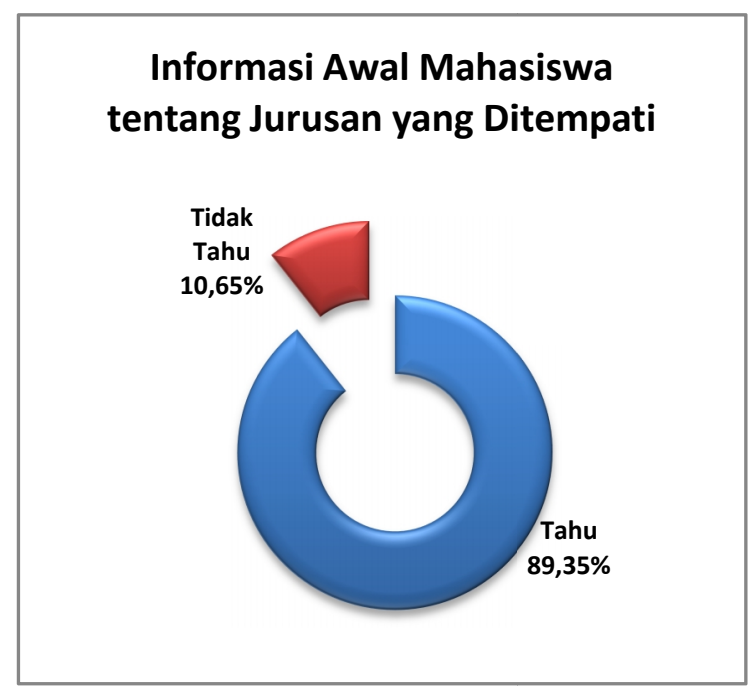

Grafik 2. Informasi Jurusan

Informasi tentang jurusan yang tersedia di perguruan tinggi tersebut diperoleh dari berbagai pihak, diantaranya Guru BK, Guru Matapelajaran, Alumni dan lain sebagainya seperti pada Grafik berikut:

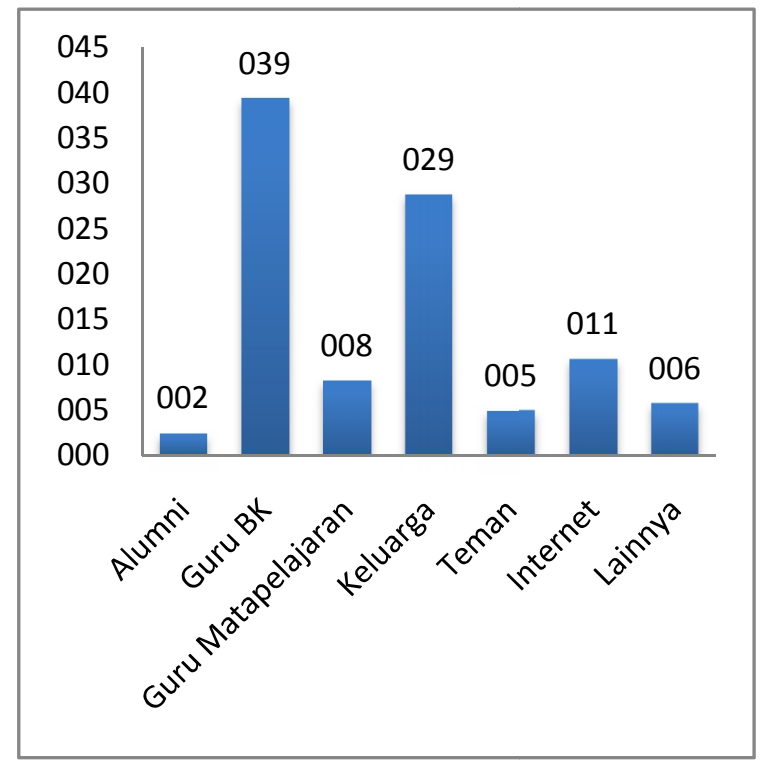

Grafik 3. Sumber Informasi Jurusan

Dari grafik di atas dapat dimaknai bahwa pada saat sebelum seleksi masuk perguruan tinggi, siswa banyak yang mendapatkan informasi dari guru
BK/Konselor (39,34\%). Informasi dari keluarga juga merupakan salah satu penyumbang terbesar, yakni $28,69 \%$ dari seluruh responden.

Meskipun demikian, permasalahan yang muncul adalah masih adanya mahasiswa yang merasa kurang dan tidak cocok dengan jurusan yang ditempatinya saat ini, meskipun telah mendapatkan informasi dari berbagai pihak di atas. Kondisi ini memberikan berbagai kemungkinan mengenai ketidakcocokan tersebut, diantara kemungkinan yang muncul adalah adanya missmatch atau ketidaksesuaian informasi yang diterima oleh siswa dalam melakukan eksplorasi jurusan yang akan ditempatinya. Kemungkinan lain yang mungkin muncul adalah adanya kekeliruan informasi mengenai jurusan yang akan ditempati siswa tersebut.

Kondisi dimaksud membutuhkan peran aktif dari guru BK/Konselor sebagai salah satu motor penggerak eksplorasi karir siswa, baik dalam menyediakan informasi karir dan perguruan tinggi yang lengkap dan memadai, maupun dalam upaya menyelami kondisi bakat serta minat peserta didik. Selain itu, dibutuhkan peran pihak-pihak sekolah yang lain dalam menyukseskan periode transisi siswa dari SLTA menuju perguruan tinggi. Selanjutnya bagi pelaksana pelayanan konseling di perguruan tinggi tempat penelitian dilakukan perlu dikembangkan program untuk mengatasi ketidakcocokan mahasiswa dengan jurusan yang telah ditempatinya.

\section{KESIMPULAN}

Aktivitas belajar yang berhasil salah satunya dipengaruhi oleh berminat atau tidaknya mahasiswa dengan jurusan yang ditempatinya. Kondisi salah pilih jurusan atau merasa tidak nyaman dengan jurusan akan membawa dampak yang signifikan 
terhadap partisipasi mahasiswa dalam proses belajar. Kondisi ini akan membawa dampak yang lebih besar apabila dibiarkan dan tidak dibenahi di masa yang akan datang. Terdapat sejumlah mahasiswa yang merasa tidak cocok dengan jurusan yang ditempatinya saat ini, meskipun telah mendapatkan beberapa informasi mengenai jurusan dimaksud. Berbagai kemungkinan dapat menjadi penyebab kondisi tersebut sehingga dengan menelusuri, maka diharapkan kondisi ketidakcocokan tersebut dapat diatasi. Peran aktif guru BK/Konselor sangat dibutuhkan dalam membantu siswa dalam memilih jurusan sesuai bakat dan minatnya, sehingga kondisi ketidakcocokan mahasiswa dengan jurusan tersebut tidak terjadi.

Studi ini memaparkan beberapa data mengenai kondisi kecocokan mahasiswa dengan jurusannya, kondisi informasi awal dan sumber informasi tersebut. Data-data yang disampaikan dalam penelitian ini selanjutnya akan dijadikan grand tour atau informasi awal dalam melakukan penelitian yang lebih mendalam mengenai pemilihan jurusan/ program studi calon mahasiswa di masa yang akan datang.

\section{DAFTAR PUSTAKA}

\section{Ahmadi, A. (1991). Psikologi \\ Perkembangan. Jakarta: Rineka Cipta.}

Albert, C., \& Garcı'a-Serrano, C. (2010). Cleaning the slate? School choice and educational outcomes in Spain. High Educ, 559-582.

http://doi.org/10.1007/s10734-0109315-9

Ardi, Z. (2014). Cita-cita Perkerjaan dan Pilihan Peminatan Siswa Sekolah Menengah Atas Negeri di Sumatera Barat. Cita-Cita Perkerjaan Dan Pilihan Peminatan Siswa Sekolah
Menengah Atas Negeri Di Sumatera Barat.

Ardi, Z., Ibrahim, Y., \& Said, A. (2012). Capaian Tugas Perkembangan Sosial Siswa dengan Kelompok Teman Sebaya dan Implikasinya terhadap Program Pelayanan Bimbingan dan Konseling. Konselor, 1(1).

Ardi, Z., \& Yendi, F. M. (2013). Konseling Online: Sebuah Pendekatan Teknologi Dalam Pelayanan Konseling. Jurnal Konseling Dan Pendidikan, 1(1), 1-5.

Babbie, E. (2010). The Practice of Social Research, Twelfth Edition. Belmont: Wadsworth.

Badan Pusat Statistik Indonesia. (2016). Jumlah Perguruan Tinggi, Mahasiswa, dan Tenaga Edukatif (Negeri dan Swasta) di Bawah Kementrian Pendidikan dan Kebudayaan Menurut Provinsi 2013/2014. Retrieved from http://bps.go.id

Brown, D. (2002). Career Choice and Development. San Francisco: John Wiley \& Sons, Inc. http://doi.org/10.2307/184400

Brown, S. D., \& Lent, R. W. (2013). Career Development and Counseling: Putting Theory and Research to Work. (2, Ed.)John Wiley \& Sons (2nd ed., Vol. 53). New Jersey: John Wiley \& Sons. http://doi.org/10.1017/CBO9781107 415324.004

Daharnis. (2005). Hubungan Sejumlah Karakteristik Mahasiswa, Kondisi Lingkungan, Pembelajaran, Kegiatan Belajar dan Prestasi Belajar Mahasiswa Universitas Negeri Padang. Universitas Negeri Malang.

Daharnis dkk. (2011). Analisis Hasil Belajar Mahasiswa Jurusan Bimbingan dan Konseling FIP UNP Ditinjau dari Mutu Kegiatan Belajar, Angkatan, status Masuk 
dan jenis Kelamin. Universitas Negeri Padang.

Daharnis, Erlamsyah, Alizamar, \& Afdal. (2011). Hubungan Aspirasi, Persepsi, Locus of Control, Angkatan dan Status Masuk dengan Kegiatan Belajar Mahasiswa Jurusan Bimbingan dan Konseling FIP UNP. Padang.

Elliot, S. ., Kratochwill, T. ., Littlefield, J. ., \& Travers, J. . (1996). Educational Psychology. Madison: Brown \& Benchmark.

Erlamsyah dkk. (2011). Hubungan Aspirasi, Persepsi, Locus of Control, Angkatan dan Status Masuk dengan Kegiatan Belajar Mahasiswa Jurusan Bimbingan dan Konseling FIP UNP (Anggota Peneliti). Universitas Negeri Padang.

Gladding, S. . (2009). Konseling: Profesi Menyeluruh (alih Bahasa oleh Winarno dan Lilian Yuwono). (Indeks, Ed.). Jakarta.

Greenhaus, J. H., \& Callanan, G. A. (2006). Encyclopedia of Career development (Vol. 53). London: SAGE Publications, Inc. All. http://doi.org/10.1017/CBO9781107 415324.004

Heppner, P. P., Wampold, B. E., \& Kivlighan, D. M. (2008). Research Design in Counseling, Third Edition. Belmont: Thomson Higher Education.

Herr, E. L., \& Cramer, S. H. (1984). Career Guidance and Counseling Through the Life Span. Boston: Little Brown.

Keller, A. C., Samuel, R., Bergman, M. M., \& Semmer, N. K. (2014). Psychological, Educational, and Sociological Perspectives on Success and Well-Being in Career Development. New York: Springer. http://doi.org/10.1007/978-94-0178911-0

Kementerian Pendidikan dan Kebudayaan.
Permendikbud nomor 81a tahun 2013 tentang Implementasi Kurikulum (2013).

Kementerian Pendidikan dan Kebudayaan. Permendikbud Nomor 111 tahun 2014 tentang Bimbingan dan Konseling pada Pendidikan Dasar dan Pendidikan Menengah (2014).

Kementerian Pendidikan dan Kebudayaan. Permendikbud nomor 58 tahun 2014 tentang Kurikulum 2013 Sekolah Menengah Pertama/Madrasah Tsanawiyah (2014).

Kementerian Pendidikan Nasional. Peraturan Menteri Pendidikan Pendidikan Dan Kebudayaan Republik Indonesia Nomor 68 Tahun 2013 Tentang Kerangka Dasar Dan Struktur Kurikulum Sekolah Menengah Atas/Madrasah Aliyah, Kementrian Pendidikan Dan Kebudayaan 1-3 (2013).

Khan, Y. A., Ahamad, Z., \& Kousar, S. (2015). Factors Influencing Academic Performance of University Students. International Journal of Educational Administration and Policy Studies, 5(November), 79-84. http://doi.org/10.15407/dse2015.02. 103

Kim, J., \& Hwang, Y. (2014). The Effects of School Choice on Parental School Participation and School Satisfaction in Korea. Soc Indic Res, 363-385. http://doi.org/10.1007/s11205-0120224-4

Klein, S., \& Washburn, S. (2012). A Case Study of the Search Phase of College Choice as Experienced Prospective Students Visiting a Midwest College of Agriculture. NACTA Journal, (December).

Kutty, F. M. (2014). Mapping their road to university: First-generation students' choice and decision of university. International Education Studies, $7(13), 49-60$. http://doi.org/10.5539/ies.v7n13p49 
Lan, C.-M. (2016). Predictors of willingness to use cyber counseling for college students with disabilities. Disability and Health Journal, 9(2), 346-52. http://doi.org/10.1016/j.dhjo.2015.11 .004

Lang, B. D., \& Lopes, V. (2014). Deciding to Transfer: A Study of College to University Choice. College Quarterly, 17(3), 1-20.

Mupemhi, S. (2013). Factors influencing choice of a university by students in Zimbabwe. African Journal of Business Management, 7(36), 37233729. http://doi.org/10.5897/AJBM2013.7 077

Nyamwange, J. (2016). Influence of Student's Interest on Career Choice among First Year University Students in Public and Private Universities in Kisii County , Kenya. Journal of Education and Practice, 7(4), 96102.

Pablo-lerchundi, I., Núñez-del-Río, M.-C., \& González-Tirados, R.-M. (2015). Career choice in engineering students : its relationship with motivation, satisfaction and the development of professional plans. Anales de Psicología, 31, 268-279.

Prayitno. (2009). Wawasan Profesional Konseling. Padang: UNP Padang.

Prayitno. (2012). Jenis Layanan dan Kegiatan Pendukung Konseling. Padang: Universitas Negeri Padang.

Santrock, J. W. (2014). Adolescence. McGraw Hill. New York: McGraw-Hill Education.

Santrock, J. W., \& Halonen, J. S. (2010). Your Guide to College Success: Strategies for Achieving Your Goals, Sixth Edition. Boston: Wadsworth Cengage Learning.

Sojkin, B., Bartkowiak, P., \& Skuza, A. (2015). Changes in students ' choice determinants in Poland : High Educ,
209-224.

http://doi.org/10.1007/s10734-014-

9770-9

Tereza, N. (2013). Analysis and Comparison of Factors Influencing University Choice. Journal of Competitiveness, 5(3), 90-100. http://doi.org/10.7441/joc.2013.03.0 7

Timothy, C. (2010). Who And What Influences Choice Of University? Student And University Perceptions. American Journal of Business Education, 3(10), 9. 